\title{
Novel harmine derivatives for tumor targeted therapy
}

\author{
Siwen $\mathrm{Li}^{1, *}$, Aqin Wang ${ }^{1, *}$, Fan $\mathrm{Gu}^{1}$, Zhaohui Wang ${ }^{1}$, Caiping Tian ${ }^{1}$, Zhiyu Qian ${ }^{2}$, \\ Liping Tang ${ }^{3}$, Yueqing $\mathbf{G u}^{1}$ \\ ${ }^{1}$ Department of Biomedical Engineering, State Key Laboratory of Natural Medicines, School of Life Science and Technology, \\ China Pharmaceutical University, Arlington, TX, USA \\ ${ }^{2}$ Department of Biomedical Engineering, School of Automation, Nanjing University of Aeronautics and Astronautics, \\ Nanjing, China \\ ${ }^{3}$ Department of Bioengineering, University of Texas at Arlington, Arlington, TX, USA \\ *These authors have contributed equally to this work
}

Correspondence to:

Yueqing Gu, e-mail: guyueqingsubmission@hotmail.com

Keywords: harmine, structural modification, 2DG, met, tumor targeting therapy

Received: November 26, $2014 \quad$ Accepted: April 04, $2015 \quad$ Published: April 22, 2015

\section{ABSTRACT}

Harmine is a beta-carboline alkaloid found in medicinal plant PeganumHarmala, which has served as a folk anticancer medicine. However, clinical applications of harmine were limited by its low pharmacological effects and noticeable neurotoxicity. In this study, we modified harmine to increase the therapeutic efficacy and to decrease the systemic toxicity. Specifically, two tumor targeting harmine derivatives 2DG-Har-01 and MET-Har-02 were synthesized by modifying substituent in position-2, -7 and -9 of harmine ring with two different targeting group2-amino-2deoxy-D-glucose (2DG) and Methionine (Met), respectively. Their therapeutic efficacy and toxicity were investigated both in vitro and in vivo. Results suggested that the two newharmine derivatives displayed much higher therapeutic effects than nonmodified harmine. In particular, MET-Har-02 was more potent than 2DG-Har-01 with promising potential for targeted cancer therapy.

\section{INTRODUCTION}

There is an increasing interest in discovering novel antitumor agents from natural resources. Harmine (7-methoxy-1-methyl-9H-pyrido[3, 4-b]indole), a naturally occurring $\beta$-carboline, was previously isolated from a medicinal herbal PeganumHarmala traditionally used in the Middle East and North Africa [1,2]. Studies in the past decade revealed that harmine possesses potent anti-proliferative and cytotoxic properties. However, harmine's severe neurotoxic effects in animal models impeded its development toward the clinical wide application [3-5].

As a small molecule, harmine may easily penetrate into cells by diffusion. However, harmine shows no tumor specificity, which may be responsible for its weak anticancer effects and serious systemic side effects [6-7]. To overcome such drawbacks, intensive research efforts have been placed on the design and synthesis of novel $\beta$-carboline derivatives with limited success [8-17]. This work summarizes our efforts on the production of harmine derivatives via targeted modifications to improve its cancer targeting effects.

The tumor targeting natural product derivatives have played an important role for the enhanced tumor therapy [18-22]. Our previous studies demonstrated that 2-amino-2-deoxy-D-glucose (2DG) and methionine (Met) exhibited wide-spectrum tumor targeting ability due to the high metabolic process in various tumor cells [23-24]. It has been commonly acknowledged that the introduction of glucose leads to increased efficiency in tumor uptake [25]. Indeed, ${ }^{18} \mathrm{FDG}$ as tumor targeting agent has been widely applied in clinicaldiagnosis [26-29]. It is well established that 2-amino-2-deoxy-D-glucose (2DG), a glucose analog, can be recognized and transported into the cells by GLUT1 on the cell membrane [30]. The absence of hydroxyl group in position 2 of 2DG hampers the isomerization in the enzyme-catalytic metabolic pathway 
and results in the retention ofphosphorylated molecule within the cell.

Methionine (Met), a sulfur containing essential amino acid indispensable for the growth and development of mammals, has been shown to play many critical roles in mammalian metabolism [31]. Methionine is transported by LAT1 and LAT2 receptors which are highly expressed in many malignant cell membranes [32]. Because of the metabolic defect in methionine production, exogenous methionine is essential to the growth of many malignant cell lines whereas the growth of non-cancerous cells is generally methionine independent. Therefore, 2DG and Met were used in this study as targeting groups to produce harmine derivatives with improved tumor selectivity.

Studies have proved that a high cytotoxic potency is associated with compounds placing hydrophobic bulky groups in position-2, -7 and -9 of harmine ring. The modifications of -2 and -9 site of harmine could enhance the antitumor activity. Thus, the methoxy- substituent at position-7 of beta-carboline might contribute to the significant neurotoxic side effect. On the other hand, the prolonged substituents at position-7 eliminated neurotoxic effects completely [9-10].

In this study, we designed and synthesized two novel targeting antitumor agents bearing 2DG and Met in position-7, phenpropyl in position-9 and benzyl in position-2 of harmine ring. The antitumor activity and neurotoxicity of these novel compounds were assessed. Subsequently, the cell targeting mechanism of the new harmine derivatives was investigated.

\section{RESULTS}

\section{Synthesis and characterization of 2DG-Har-01 and MET-Har-02}

2DG-Har-01 and MET-Har-02 were synthesized by following the series of steps as depicted (Fig. 1A). The $\mathrm{N}^{9}$-alkylated harmine derivative 2 was prepared according to the synthetic protocol described before [33]. The preparation of compounds 3 followed a common synthetic scheme [34], characterized by demethylation of compounds 2 using acetic acid and hydrobomic acid as reaction solvent. To modify the molecules with 2DG and Met, a key intermediate, the alky halide, was designed. Compound 4 was obtained by O-alkylation of compound 3 in the presence of cesium carbonate with the ethyl bromoacetate. Then, hydrolyzation of compound 4 lead to the production of $-\mathrm{COOH}$-functionalized compound 5. Finally, 2DG-Har-01 and compound 6 were synthesized with the conjunction of 2DG and Met, respectively. MET-Har-02 is the $\mathrm{N}^{2}$-benzylated product of compound 6. The successful synthesis of 2DG-Har-01 and MET-Har-02 were evidenced by MS (Fig.1B, 1C) and ${ }^{1} \mathrm{H}$ NMR (Fig. 1D, 1E). The molecular weights of 2DGHar-01 and MET-Har-02 are 536 and 596, respectively (Fig. 1B, 1C).

\section{Proliferative inhibition assay}

We investigated the anticancer effects of 2DGHar-01, MET-Har-02 on five human cancer cell lines

A

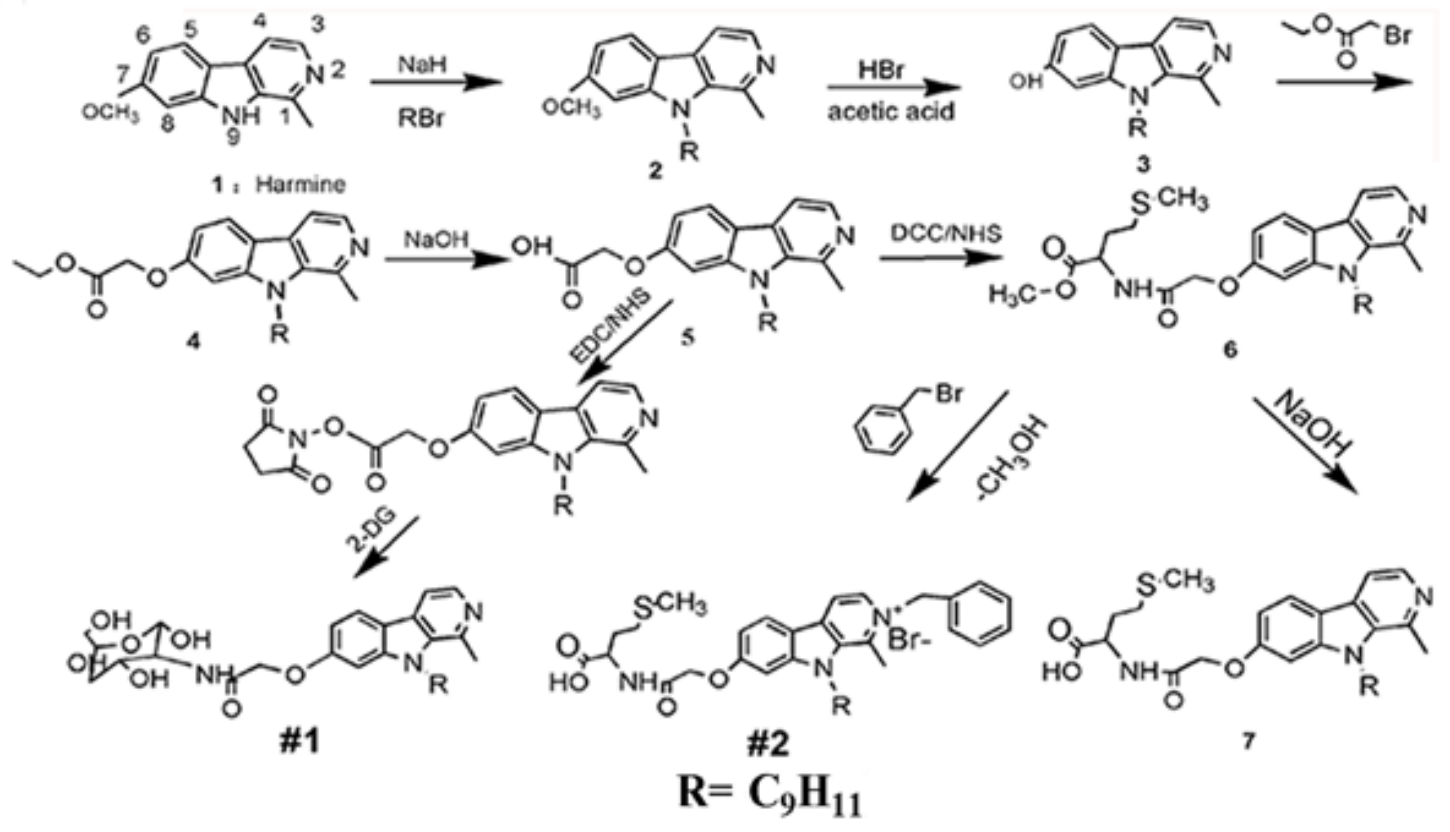

Figure 1: A. synthetic scheme of harmine derivatives 2DG-Har-01 and MET-Har-02. 


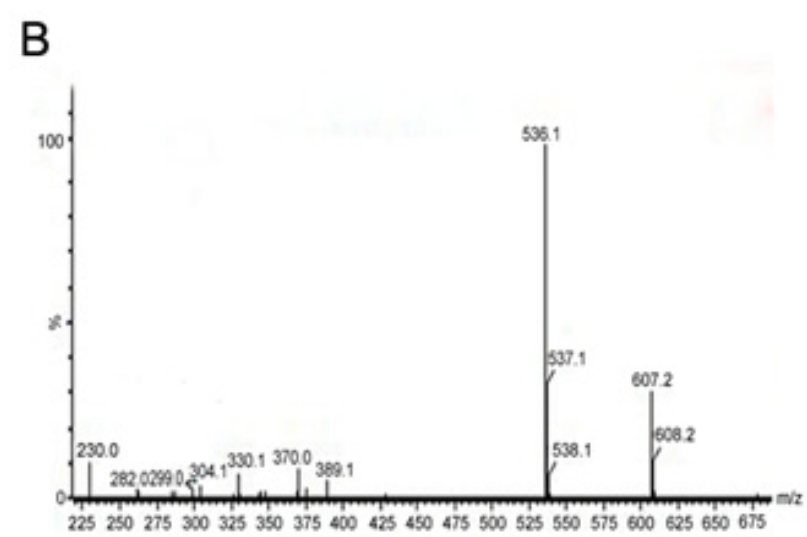

D

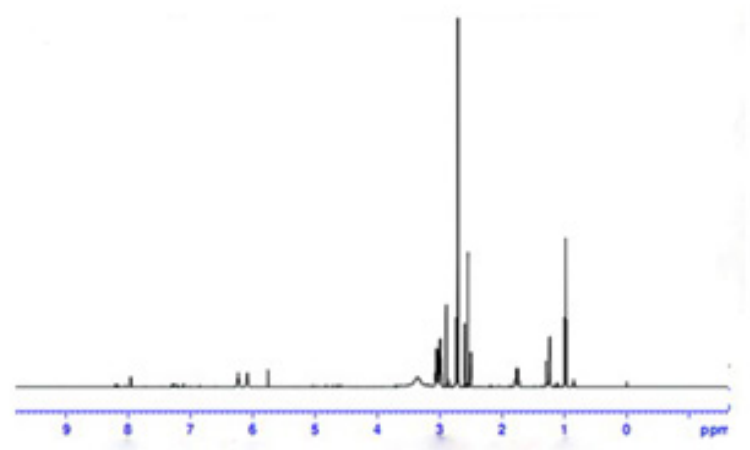

C

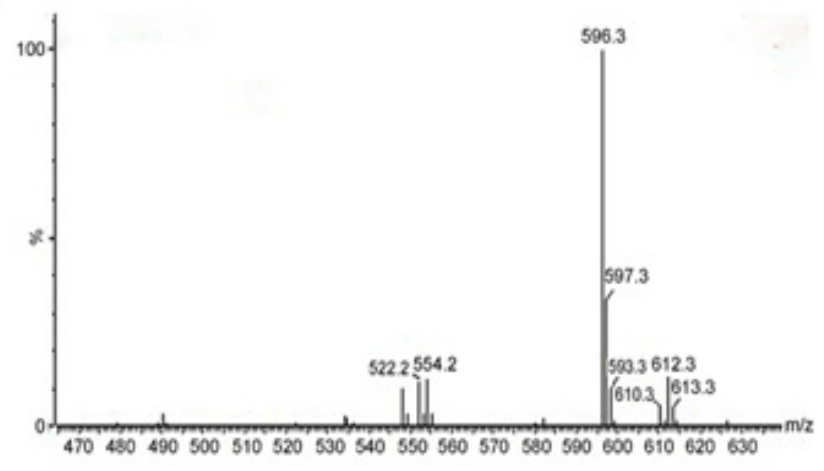

E

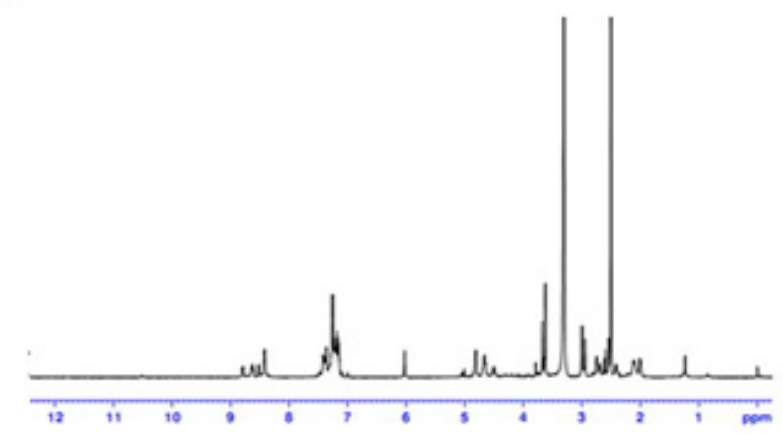

Figure 1 (Continued): B. and C. Mass spectrums of 2DG-Har-01 (B) and MET-Har-02 (C) D. and E. ${ }^{1} \mathrm{H}-\mathrm{NMR}$ spectrums of 2DG-Har-01 (D) and MET-Har-02 (E).

(SMMC-7721, HuH7, HepG2, LOVO and MCF-7). The original harmine and common recognized anticancer drug 5 -fu were used as control. As shown in Fig. 2A-2E, the modified harmine derivatives, 2DG-Har-01 and METHar-02, showed dose-dependent anti-tumor activity in different concentrations. 2DG-Har-01 showed improved antitumor activities than harmine controls on LOVO and SMMC-7721 cells. On the other hand, MET-Har-02 displayed stronger antitumor activity than harmine controls and 5-fu on all cell lines, especially hepatocellular carcinoma cells (SMMC-7721, HuH7).

Most importantly, unlike harmine control and 5-fu, the targeting compounds 2DG-Har-01 and MET-Har-02 showed slight cytotoxicity on the normal human liver cell L-02 even at the highest concentration $(200 \mu \mathrm{M})$ (Fig. 2F). These highly selective toxicity results support that 2DG-Har-01 and MET-Har-02 might be uptaken mostly by cancer cells rather than normal cells. The effect of MET-Har-02 and harmine on cancer cells was further investigated using clone formation assay on HepG2 cells. After treated with indicated concentration of MET-Har-02 and harmine for 7 days, the number of clones formed was significantly decreased compared with the control group, (Fig. $2 \mathrm{G}, 2 \mathrm{H}$ ). At $5 \mu \mathrm{M}$, both MET-Har-02 and harmine were found to inhibit HepG2 cells' colony formation while
MET-Har-02 showed superior suppression effect than harmine. No colony was found when the concentration of MET-Har-02 was raised to $10 \mu \mathrm{M}$.

\section{The apoptosis assay of harmine and MET-Har-02}

Further studies were carried out to seek the potential processes governing the anti-tumor effect of MET-Har-02 and harmine. Since many anticancer drugs cause the death of tumor cells through the induction of apoptosis, we thus assume that MET-Har- 02 promotes cancer cell apoptosis. This hypothesis was tested using HepG2 cell line. As expected, the treatment of MET-Har-02 and harmine both decreased the survival of HepG2 Cells (stained with hoechst) and the cell survival rates were decreased with increasing the compounds concentrations (from 0 to $10 \mu \mathrm{M})$ (Fig. 3A). It also suggested that the antitumor activity of MET-Har-02 is better than the hamrine's (the amounts of the cells in the same concentration).

Morphological analysis was performed after METHar-02 and harmine treatment for 48 hours. HepG2 Cells were stained with Hoechst 33342 for 20 mins and observed through the confocal laser scanning microscope. As shown in (Fig. 3B). The density of cells was decreased with the 

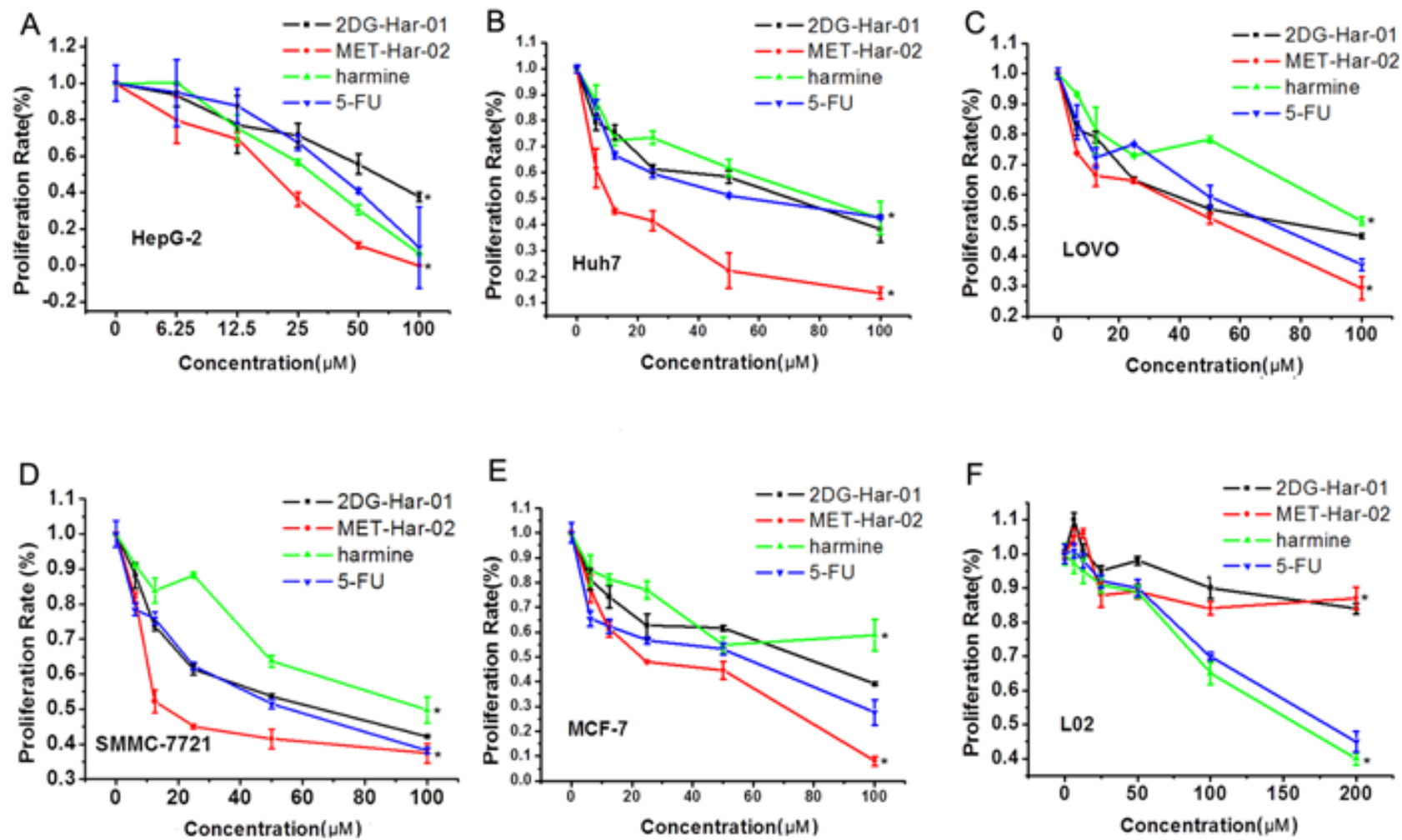

G

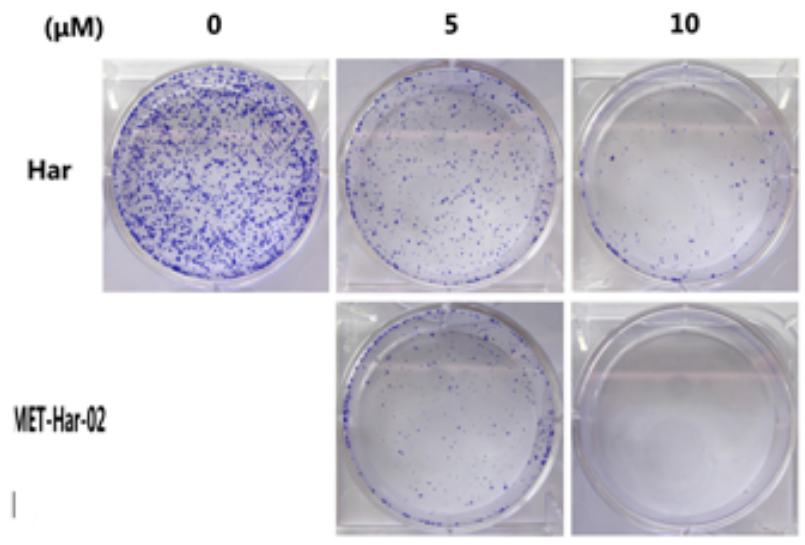

$\mathrm{H}$

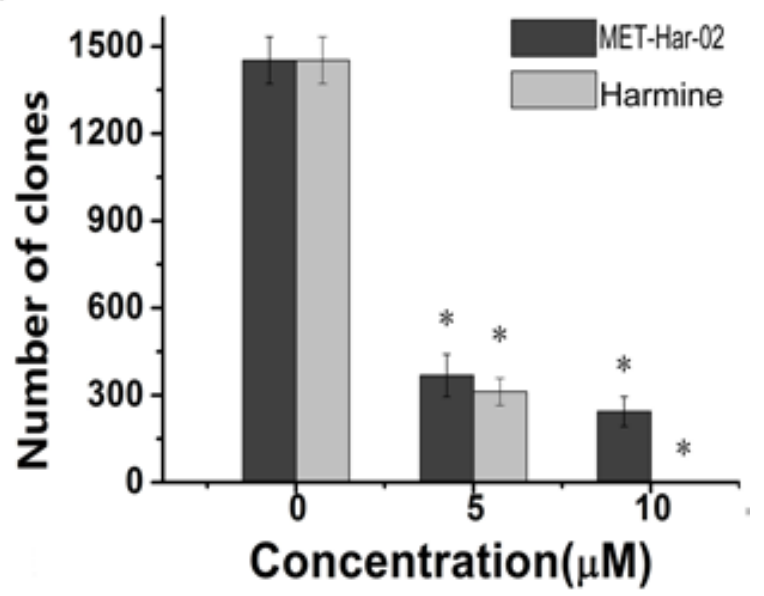

Figure 2: (A-F) In vitro antitumor efficacy and cytotoxicity of 2DG-Har-01 and MET-Har-02. Tumor cell proliferation rate of HepG-2 cells A. Huh7 cells B. LOVO cells C. SMMC-7721 cells D. MCF-7 cells E. and normal liver cell L02 F. incubated with either 2DG-Har-01, MET-Har-02, harmine or 5-FU. G. and H. Clone formation assay was performed on HepG2 cells. The cells incubated with either harmine (Har) or MET-Har-02 with different concentration $(0,510 \mu \mathrm{M})$. Data are given as mean $\pm \operatorname{SD}(n=5) .{ }^{*} P<0.05$.

increasing concentration of the compounds. Cells in the control group fully stretched and showed normal volume. Morphological changes such as cell shrinkage, rounding, nuclear condensation and margination were observed when the cells were treated with MET-Har-02 at $10 \mu \mathrm{M}$ and $15 \mu \mathrm{M}$, but not very obvious in the harmine group.

Annexin V-FITC/PI double labeling method was used to detect apoptosis of HepG2 cells after harmine and
MET-Har-02 treatments.Annexin V specifically recognized the cells entering apoptosis that expressed phosphatidyl serine on the outer layer of the cell membrane. Necrotic cells can be stained only with PI, early apoptotic cells with annexin $\mathrm{V}$ and late apoptotic cells with both annexin $\mathrm{V}$ and PI. Double staining by annexin V and PI allows the discrimination of apoptotic cells from necrotic cells. After treatment of MET-Har-02 in concentration of $7.5 \mu \mathrm{M}$ for 
A

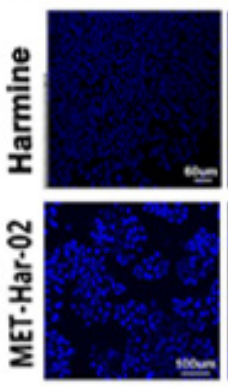

0

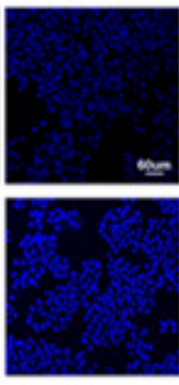

2.5
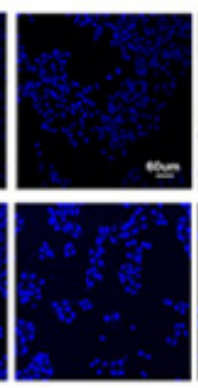

5

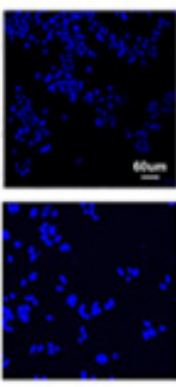

10

Concentration $(\mu \mathrm{M})$

C
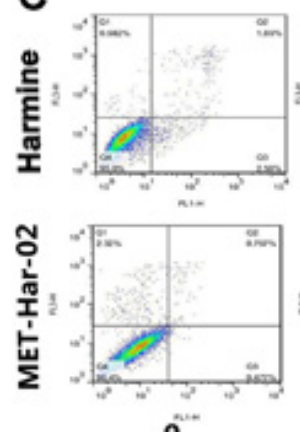

o
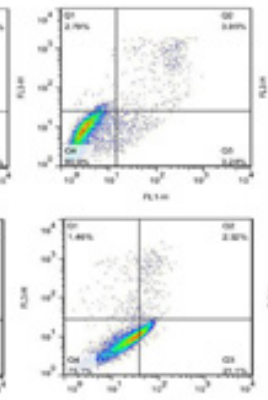

$7.5 \mu \mathrm{M}$
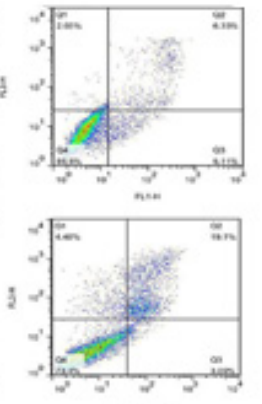

$15 \mu \mathrm{M}$

Concentration $(\mu \mathrm{M})$

B
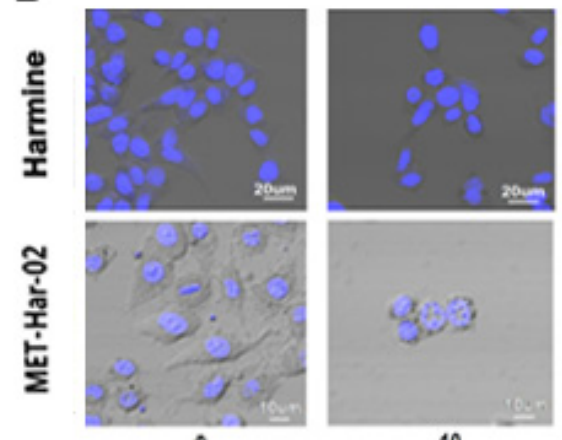

10

Concentration $(\mu \mathrm{M})$
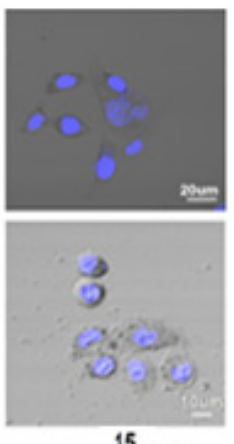

15

D

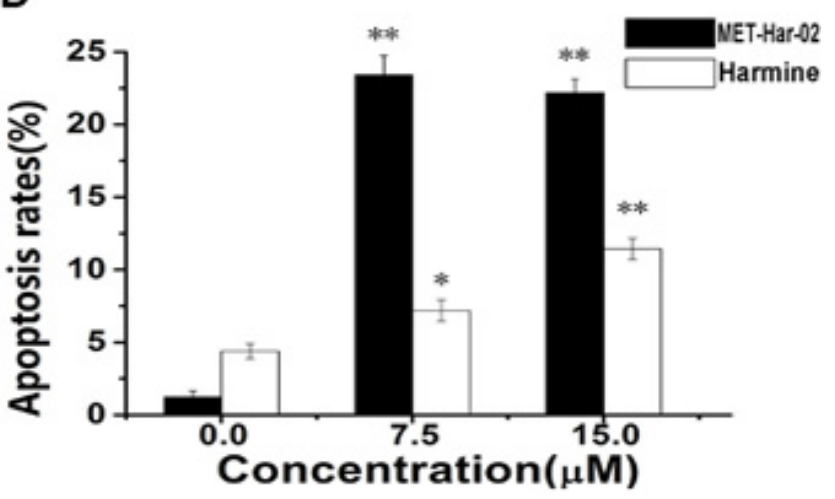

Figure 3: The apoptosis in HepG2 cancer cells after incubated with MET-Har-02 and harmine. A and B. Morphological changes in apoptotic cells were examined by LSFM microscopy after hoechst staining (original magnification, $\times 100$ ). C. Flow cytometrybased annexin V-FITC/PI labeling of apoptotic cells. D. The histogram represents apoptosis rates. Data are given as mean \pm SD $(n=10) . * * P<0.01$.

$24 \mathrm{~h}$, the amount of cells in the right bottom quadrant (cells in early apoptosis) increased by $21 \%$ (Fig. 3C and 3D). When the concentration of MET-Har-02 was increased to $15 \mu \mathrm{M}$, almost the entire early apoptotic cells were transformed into late apoptosis (Fig. 3C and 3D). Apoptosis was also observed in cells treated with harmine. Even at the presence of $15 \mu \mathrm{M}$ harmine, only $7 \%$ cell apoptosis was observed (Fig. 3D). The early apoptosis to late apoptosis was estimated to be 1:1 ratio.

\section{In vivo antitumor activity of 2DG-Har-01 and MET-Har-02}

The in vivo anti-tumor efficiency of 2DG-Har-01 and MET-Har-02 were evaluated in S180 tumor-bearing mice following the procedures described in section method. As shown in Fig. 4A, the tumor growth was significantly reduced in the mice groups treated with 2DGHar-01, MET-Har-02 and Harmine compared with salineinjection control group. Among all treatments, METHar-02 showed highest tumor inhibition ratio $(67.86 \%)$ compared to 2DG-Har-01 (42.84\%) and Harmine $(30.93 \%)$ treatment. The tumors isolated from the subject mice after 16 days treatment confirmed the in vivo tumor measurements (Fig. 4B). Body weight and survive rate usually reflect the health condition of the treated mice. The body weight of mice in the control group (salinetreated) began to decrease from the $8^{\text {th }}$ dayafter injection (Fig. 4C), which indicated the living quality of the mice was compromised by the tumor burden. For the 2DGHar-01 and MET-Har-02 treated groups, the body weight gradually increased during the treatment period, implying that the systemic toxicity was minimal in these mice. A slightly decrease of body weight in the harmine group was observed at the end of the treatment period. During the in vivo studies of 16 days (Fig. 4D), no mice died with the 2DG-Har-01 treatment. For the same duration, the survival rate of MET-Har-02 group was $90 \%$ and harmine group was $80 \%$ while only $30 \%$ of animals survived with saline injection. These results support that the newly synthesized targeting reagents 2DG-Har-01 and METHar-02 treatment may prolong the life expectance of S180 tumor-bearing mice.

Similarly the antitumor efficacy of MET-Har-02 was also investigated on the MCF-7 tumor bearing nude mice. As shown in Fig. 4E, the tumor volume indicated 
A

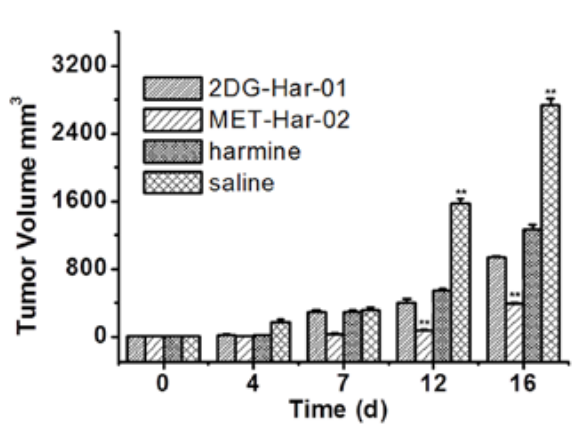

C

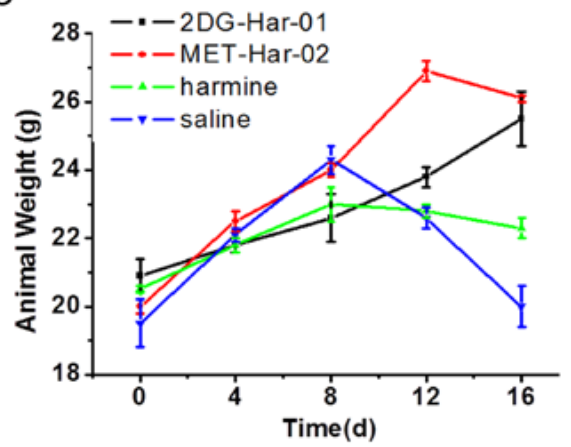

E

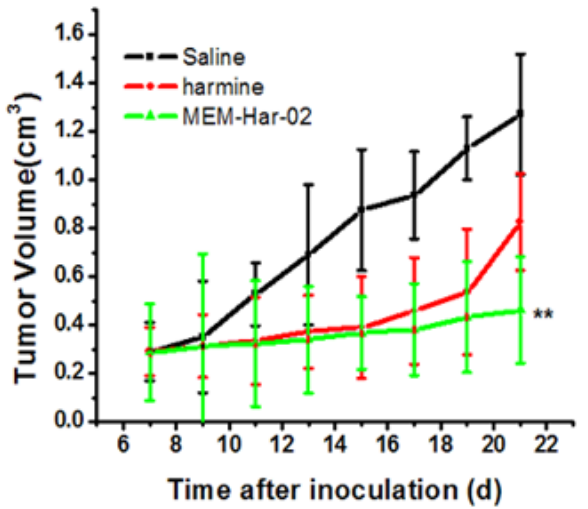

G

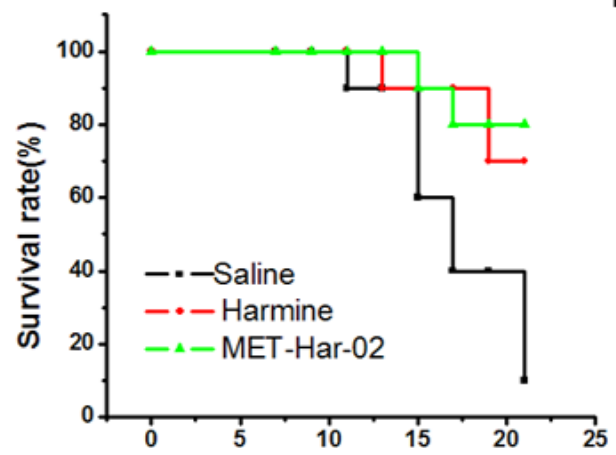

B

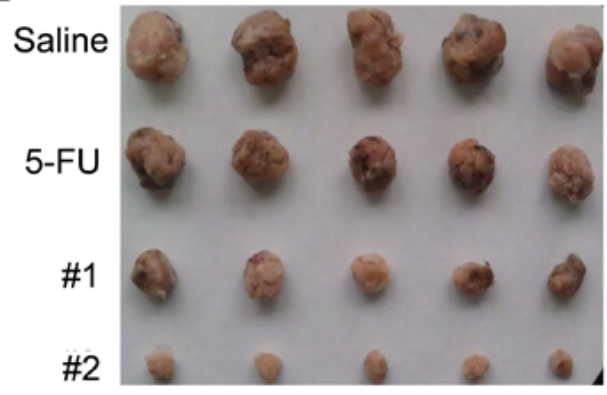

D

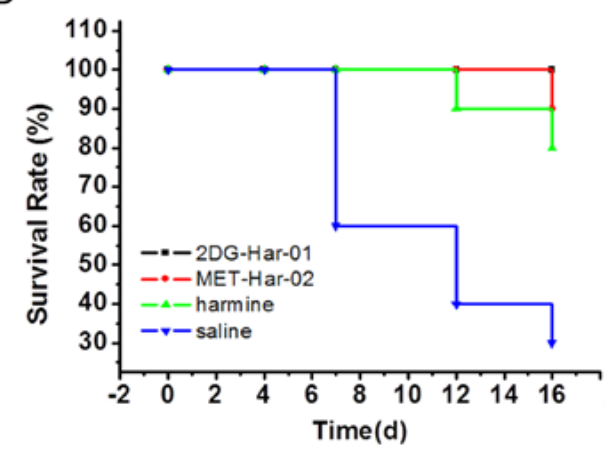

$\mathrm{F}$

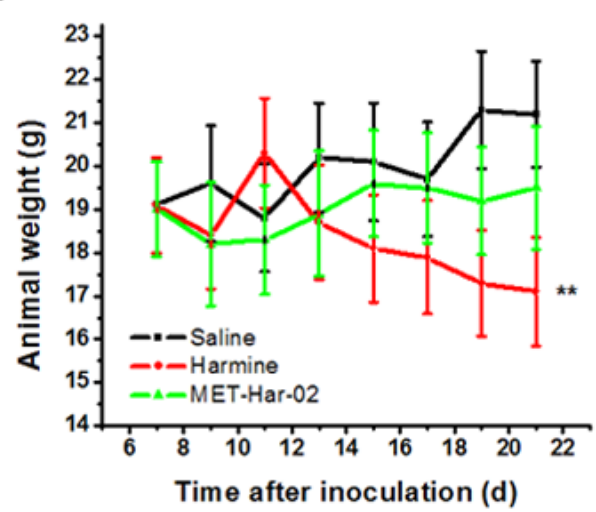

$\mathrm{H}$

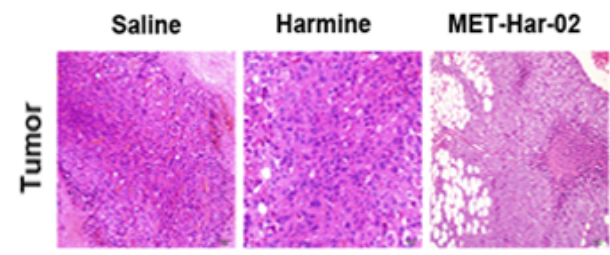

Figure 4: In vivo antitumor efficacy of 2DG-Har-01 and MET-Har-02 on S180 tumor-bearing mice and MCF-7 tumorbearing nude mice. A. tumor volume of mice-bearing S180 tumors under different treatments (2DG-Har-01, MET-Har-02, harmine and saline, $n=10$ /group). B. tumor picture of mice-bearing S180 tumors in different groups (2DG-Har-01, MET-Har-02, harmine and saline) on the 16th day after injection. C. body weights of mice bearing S180 tumors in different groups. D. the 16-day survival rates of mice after administration of 2DG-Har-01, MET-Har-02, harmine and saline. E. tumor volume of nude mice-bearing MCF-7 tumors under different treatments (MET-Har-02, harmine and saline, $n=10$ /group). F. body weights of mice bearing MCF-7 tumors in different groups. G. the 21-day survival rates of mice after administration of MET-Har-02, harmine and saline. H. the histology examination of tumor on different group. 
that MET-Har-02 exhibited higher tumor inhibition ratio than harmine, with the inhibitionratios of $63.5 \%$ (MET-Har-02) and 35\% (harmine). The body weights of subjected nude mice were plotted in Fig. 4F. Compared to the saline group, the MET-Har-02 group didn't show obvious reduction of weight during the 21 days. The 21-day survival rates of micebearing MCF-7 tumors in the MET-Har-02 and harmine groups were $80 \%$ and $70 \%$, respectively, whereas in the control group only one nude mouse was still alive on the $21^{\text {th }}$ day (Fig. 4G). We also performed the pathological examination on the tumor tissues (Fig. 4H). The result showed pronounced pathological changes in the MET-Har-02 group. The most amounts of the tumor cells were dead in the central of the issue and the volume of the surrounding cells decreased obviously, which was similar to the results of antitumor efficacy in the study above.

\section{Neurotoxic and acute toxicities assay on normal mice}

Neurotoxic of 2DG-Har-01, MET-Har-02 and harmine were evaluated both in vivo and in vitro. As shown in Table 1, the healthy mice treated with 2DGHar-01 and MET-Har-02 (10, 50, 100, 200 and 500 mg/ $\mathrm{kg}$, i.p.) did not exhibit signs of neurotoxicity, such as tremor, tetanus, twitch, jumping, supination and death during the 10-day observation. As expected, the mice receiving $100 \mathrm{mg} / \mathrm{kg}$ harmine exhibited neurotoxic behaviors immediately (Table 1). Moreover, the nerve cell toxicity of these compounds was assessed using PC12 rat neural cells and MTT assay (Fig. 5A). The study showed that the cell survival rate of harmine treated group was 39\%, while 2DG-Har-01 and MET-Har-02 treated groups were more than $80 \%$ at the drug concentration of $200 \mu \mathrm{M}$. These observations suggested that the modified harmine derivatives 2DG-Har-01 and MET-Har-02 have reduced neural toxicity.

Further, the acute toxicities were investigated. Compared with the saline control group, the animal body weight after the treatments of 2DG-Har-01 and METHar-02 even at the high concentration of $500 \mathrm{mg} / \mathrm{kg}$ displayed a regular increasing trend, without obvious toxicity (Fig. 5B). In contrast, harmine treated mice group exhibited the inhibited growth (Fig. 5B). Further study was carried out to determine the organ coefficient (ratio of organ weight/body weight) of the major organs (heart, liver, spleen, lung and kidney) in animals treated with $500 \mathrm{mg} / \mathrm{Kg}$ 2DG-Har-01, MET-Har-02, in the $10^{\text {th }}$ day after injection (Fig. 5C). As expected and in consistent with the animal weight results, the administration of harmine significantly increased liver weight indicating liver toxicity (Fig. 5C). On the other hand, two modified harmine derivatives did not render any significant changes in the organs compared with the control group, except a slight swelling of liver in MET-Har-02 treated animals. To further study the acute toxicity, the serum levels and pathological assay for the main organs were investigated at 10 days after injection of different compounds. As shown in Fig. 5D, the serum levels of AST, ALT, CK and BUN in the harmine treated mice group demonstrated significant elevation $(p<0.01)$, while only slight increasing were observed in the MET-Har-02 treated mice group for AST, ALT, BUN. The levels of CK induced by MET-Har-02 were almost the same with the control group, indicating low toxicity of the modified compound MET-Har-02. To confirm the toxicity, we also did the histological examination for the main organs (heart, liver, lung and kidney) from the above three groups (10/ group) (Fig. 5E). The heart and lung showed no obvious pathological changes in mice of all the three groups. In the liver examination, no pathological damage was observed in the saline and MET-Har-02 group, but a little hepatic edema was found in the harmine group. The observation of kidney revealed a little pathological damage in both harmine and MET-Har-02 groups. However, the damage in harmine group was more serious than that in the METHar-02 group.

\section{DISCUSSION}

In this study, we presented the derivative synthesis of harmine, a beta-carboline alkaloid, with both molecular modification and targeting agent conjunction [10]. The purpose of the molecular alteration was to acquire new compounds of highly potent antitumor activity and low neural and systemic toxicity. Previous studies have concluded that a higher antitumor efficacy potency of harmine is associated with the compounds bearing hydrophobic bulky groups in position-7 and -9 . However, the methoxy substituent at position-7 of beta-carboline might be responsible for their severe neurotoxic effect.

Table 1: Neurotoxic behaviors of the mice treated with 2DG-Har-01, MET-Har-02 and harmine

\begin{tabular}{|l|c|c|c|c|c|}
\hline \multicolumn{1}{c}{} & Tremor & Tetanus & Twitch & Jumping & Supination \\
\hline 2DG-Har-01 & - & - & - & - & - \\
\hline MET-Har-02 & - & - & - & - & - \\
\hline Harmine & $\sqrt{ }$ & $\sqrt{ }$ & $\sqrt{ }$ & $\sqrt{ }$ & $\sqrt{ }$ \\
\hline
\end{tabular}


A

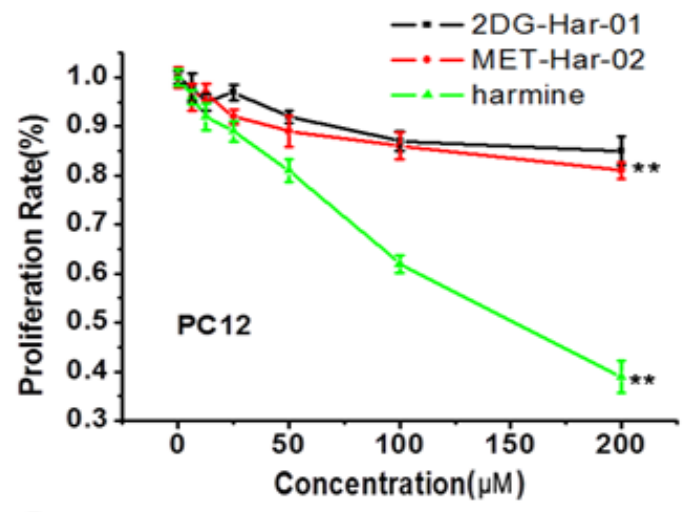

C
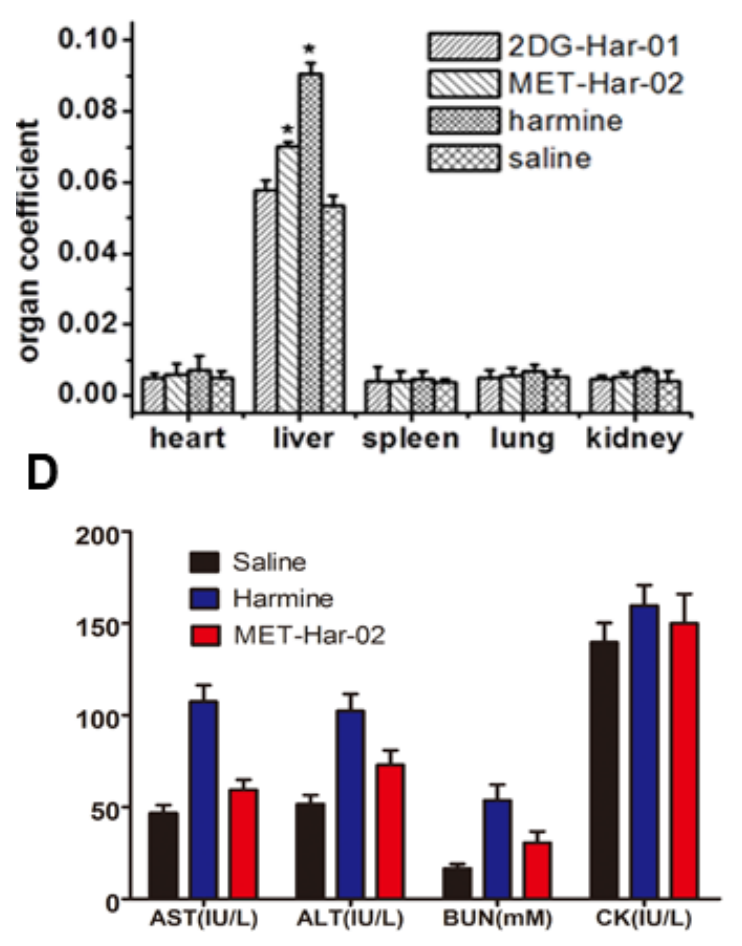

B

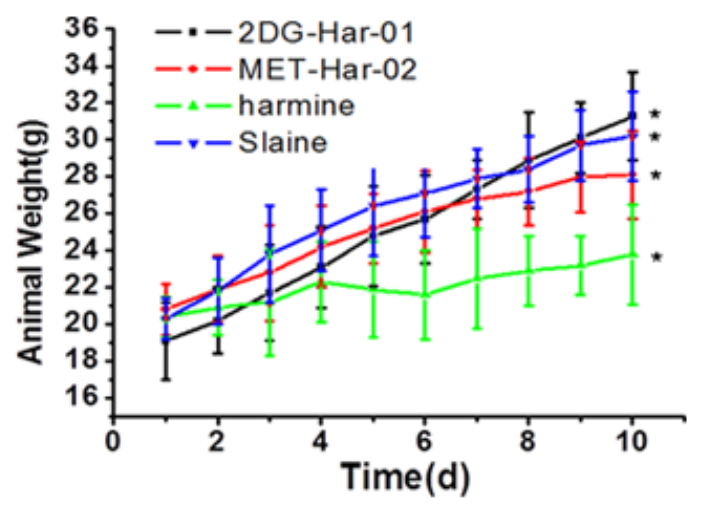

E

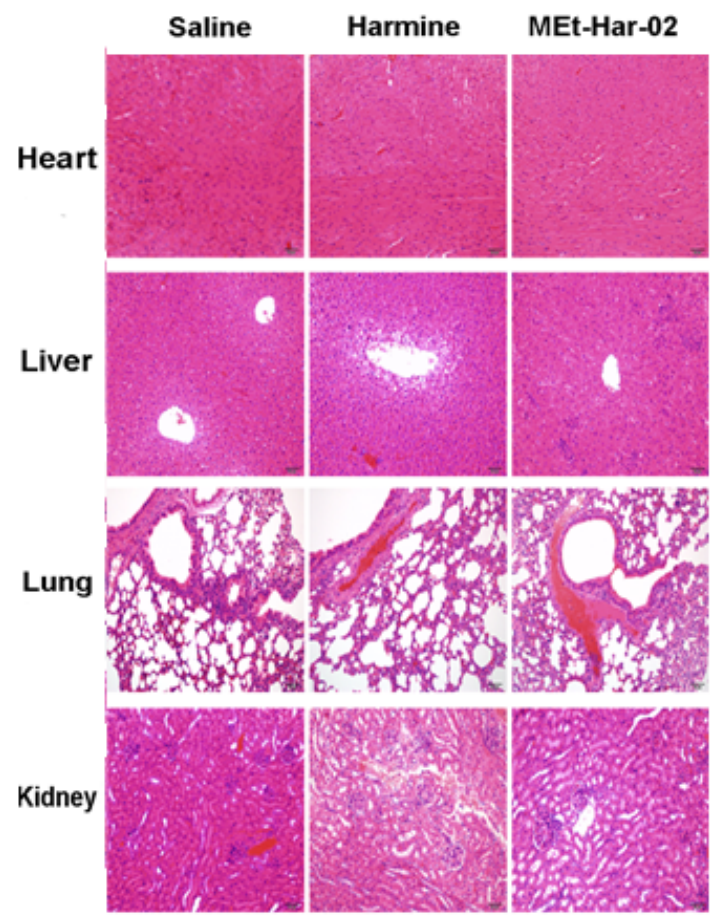

Figure 5: The neurotoxic and acute toxicities of 2DG-Har-01 and MET-Har-02 on healthy mice. A. the proliferation rate of the mice neural cells PC12 incubated with 2DG-Har-01, MET-Har-02 and harmine. Data are given as mean $\pm \operatorname{SD}(n=10)$. ** $P<0.01$. B. animal weights of normal mice in different groups (2DG-Har-01, MET-Har-02, harmine and saline). C. organ coefficient (organ weight/ animal weight) of normal mice in different groups (2DG-Har-01, MET-Har-02, harmine and saline) on the 10th day. D. the blood serum index (AST, ALT, BUN, CK) of the mice after the acute toxicities test. E. The histology examination on main organ of different mice group (MET-Har-02, harmine and saline treated).

To eliminate the neural toxic effects, harmine derivatives were synthesized with prolonged substituents at position-7. The 2DG and MET as the tumor targeting agent were documented in our previous studies. Indeed, the conjugation of $2 \mathrm{DG}$ at position-7 using a reaction linkage with methyl bromoacetate significantly increase the tumor cell uptake ability and decrease the neurotoxicity effect. And furthermore we added a hydrocinnamyl at position-9 to enhance the cytotoxicity of the compounds $[2,8]$. As anticipated, our results showed that 2DG-Har-01 had better antitumor activity than harmine. To further improve the anti-tumor property, MET-Har-02 bearing $\mathrm{N}_{2}$-benzylated modification in position 2 was produced. Benzyl in position-2 of harmine was reported to have significant contribution to the anti-proliferation effect of harmine derivatives $[3,8,10,20]$. It should be noted that, possibly due to the steric hindrance of 2DG, benzyl cannot be modified on the position-2 of 2DG-Har-01 (the stereospecific blockade and demonstrated by our study). Both our in vitro and in vivo results support that both 
derivatives, MET-Har-02 and 2DG-Har-01, have superior antitumor property and cell/animal safety than harmine.

These all in vitro and in vivo experiment results have manifested that structural modification in position 2 , 7,9 of harmine could improve the antitumor activity and decrease the side effects of the compounds. The reason of the ideal results is that the targeting agent modifications reduce the uptake of other organs and the molecular modifications enhance the antitumor activity to the cancer cells.

Subsequent work was emphasized on identifying the antitumor mechanism of MET-Har-02. Since harmine and many other beta-carboline agents have been shown to kill tumor cells by launching apoptosis [21], we have hypothesized that MET-Har-02 trigger cancer cells undergone apoptosis. This hypothesis is supported by several observations. Firstly, Annexin V-FITC/PI double labeling assay showed that different concentration of MET-Har-02 induced apoptosis on different phases. These results were also confirmed by Hoechst staining. Second, while non-treated cells fully stretched and showed normal volume, treated ones showed typical apoptotic cell morphology with shrunk, turned round, presented condensed nuclear and margination. These finding supports our assumption that the anti-proliferative effects of MET-Har-02 may be attributable to its induction of apoptotic cell death.

Apoptosis may be mediated by different pathways. Briefly, caspase, a family of cysteine proteases, is an integral part of the apoptotic pathway. Moreover, mitochondria mediated apoptosis is precisely regulate by $\mathrm{Bcl}-2$ family proteins. Furthermore, the $\mathrm{Bcl}-2 / \mathrm{Bax}$ ratio is known as the 'molecule trigger' of apoptosis [35]. Interestingly, METHar-02 has insignificant influence on the ratio of Bcl-2/ Bax. These results indicate that MET-Har-02 may have no effect on the Bcl family proteins in HepG2 cell at the test condition (Supplementary materials 1 )

It is well known that cell apoptosis and the cell cycle are tightly linked. According to former researches, several beta-carboline compounds, including harmine, change the cell cycle thorough specific inhibition of CDKs which are crucial molecules in the regulation of different phases of the cell cycle [36]. Our data showed that MET-Har-02 caused cell cycle arrest in the G1 phase of HepG2 cell, which was distinct from the known antitumor effect of harmine. In addition, wound scratch results have shown that the MET-Har-02 suppresses tumor metastasis even at a low concentration of $5 \mu \mathrm{M}$ (Supplementary materials 2).

\section{MATERIALS AND METHODS}

\section{Reagents}

Harmine (MW 212.24, $\geq 98 \%$ purity) was purchased from Xi'AnFeida Bio-Tech CO. LTD (Xi'An China). All solvents and reagents used in this study were analytical reagent grade, and obtained from Aladdin (Shanghai, China). Silica gel $\mathrm{GF}_{254}$ was used in analytical thin-layer chromatography (TLC) and silica gel was used in column chromatography. D-(+)Glucosamine hydrochloride (MW 164.16) and Methionine (MW 149.21), RPMI-1640, dimethylsulfoxide (DMSO), hoechst 33342 and 3-(4, 5-dimethylthiazol-2-yl) -2, 5-diphenyl tetrazolium bromide (MTT) fetal bovine serum (FBS), streptomycin, penicillin, and trypsin-EDTA were purchased from commercial sources. Antibodies specific for caspase- 8 were purchased from Cell Signaling Technology (city, country). Antibodies specific for caspase-9, Bcl-2, Bcl-xL, and GAPDH were purchased from Epitomics (Zhejiang, Nanjing).

\section{Cell lines and cell culture}

Human hepatoma cell lines SMMC-7721, HuH7, HepG2, human pancreatic cancer cell line PC-3, human lung cancer cell A549, human breast cancer MCF-7 and immortal hepatic cell lines L02 cell line, human colorectal LOVO cell line were purchased from Cell Bank of Shanghai Institute of Biochemistry \& Cell Biology, Chinese Academy of Sciences (Shanghai, China). All cell lines were routinely cultured at $37^{\circ} \mathrm{C}, 5 \% \mathrm{CO} 2$ in RPMI 1640 or DMEM with $10 \%$ fetal bovine serum (FBS), $5 \%$ penicillin/streptomycin.

\section{Animal subjects}

All normal (Kunming) mice were purchased from Charles River Laboratories (Shanghai, China). S180 sarcoma cell lines were provided by Shanghai Institute of Pharmaceutical Industry. All animal experiments were carried out in compliance with the Animal Management Rules of the Ministry of Health of the People's Republic of China (document NO. 55, 2001) and the guidelines for the Care and Use of Laboratory Animals of China Pharmaceutical University.

\section{Methods}

Synthetic routine of 2DG-Har-01 and MET-Har-02 were described as scheme 1 (Fig. 1A). All synthetic steps were divided into three parts. Part I: Modification ofharmine in positon-7 and- 9, gave harmine derivatives (2), (3), (4) and non-targeted harmine derivative (5). Part II: Targeting modification of harmine derivatives with 2DG and Met provided 2DG-Har-01 and compound (6), respectively. Part III MET-Har-02 was finally prepared through Modification of compound (6) in position-2.

\section{Synthesis of 7-methoxy - 9-(3-phenylpropyl)- 1-methyl- $\beta$-carboline (compound 2)}

A mixture of 7-methoxy-1-methyl- $\beta$-carboline (compound 1:harmine) $(0.530 \mathrm{~g}, 2.5 \mathrm{mmol})$, anhydrous 
DMF(15 mL) and $\mathrm{NaH}(0.090 \mathrm{~g}, 3.75 \mathrm{mmol})$ was stirred about 5 minutes at room temperature (RT) until it was clear, and then 3-phenylpropyl bromide (0.995 g, $5 \mathrm{mmol})$ was added. The mixture was stirred continually about 3-4 h at RT. After completion of the reaction as indicated by TLC (petroleum ether/acetone 1:1), the solution was poured into cold water $(30 \mathrm{~mL})$, stirred for 20 minutes, and then the yielded precipitate was filtered and washed with considerable water. The precipitate was dissolved in ethanol and adjusted to $\mathrm{pH} 3-4$ by $\mathrm{HCl}$, and then the ethanol was removed on the rotary evaporator. The white solid was recrystallized from acetone, and hydrochloride of compound $\mathbf{2}$ was obtained.

Yield $=100 \%, \mathrm{R}_{\mathrm{f}}=0.55$ (petroleum ether/ acetone1:1) ESI-MS m/e (M + 1) 331.2.IR (KBr, $\left.\mathrm{cm}^{-1}\right)$ 2059, 1619, 1544, 1473, 1441, 1407, 1345, 1250, 1207, $1140,1034,813,743$

${ }^{1} \mathrm{H}-\mathrm{NMR}(500 \mathrm{MHz}, \mathrm{CDCl} 3)$ 88.23-8.24 (1 H, d, $\mathrm{J}=5.1 \mathrm{~Hz}) ; 7.81-7.82(1 \mathrm{H}, \mathrm{d}, \mathrm{J}=5.13 \mathrm{~Hz})$; 8.10-8.08 (1 H, d, J = 8.6 Hz); 7.11-7.12 (1 H, m); 6.86-6.88 (1 H, m); 7.11-7.30 (5 H, m); 3.90 (3 H, s); 3.15 (3 H, s); 2.01-2.03 (2 H, m); 4.52-4.55(2 H, m); 2.70-2.73(2 H, m) ${ }^{13}$ C-NMR (500 MHz, CDCl3) $\delta 163.7$, $146.2,139.7,135.9,133.7,133.6,128.8,128.7,128.3,126.6$, $123.8,113.4,112.8,92.7,76.9,55.8,44.2,32.5,31.5,17.2$.

\section{Synthesis of 7-hydroxy - 9-(3-phenylpropyl)- 1-methyl- $\beta$-carboline (compound 3)}

Hydrobromic acid $40 \%$ aqueous $(20 \mathrm{~mL})$ was added to the solution of hydrochloride of compound 2 (0.825 g, $2.5 \mathrm{mmol})$ in glacial acetic acid $(20 \mathrm{~mL})$. The solution was heated to reflux for $12 \mathrm{~h}$. After completion of the reaction as indicated by TLC, the mixture was cooled and poured onto ice. The aqueous mixture, made basically with sodium hydroxide and sodium bicarbonate, yielded a precipitate that was filtered and dried. The solid was crystallized from anhydrous ethanol. White crystals were obtained.

Yield $=95 \%, \mathrm{R}_{\mathrm{f}}=0.58$ (petroleum ether/acetone $1: 1$ ). ESI-MS m/e (M + 1) 317.4. IR (KBr, cm-1) 3471-2200, $1640,1565,1493,1411,1338,1247,1194,1164,1117$, 1021, 807, 747 1H-NMR (500 MHz, CDCl3) 89.72 (1 H, s, OH); 8.23-8.24 (1 H, d, J = 5.1Hz); 7.81-7.82 $(1 \mathrm{H}, \mathrm{d}, \mathrm{J}=5.13 \mathrm{~Hz}) ; 8.10-8.08(1 \mathrm{H}, \mathrm{d}, \mathrm{J}=8.6 \mathrm{~Hz})$; 7.11-7.12 (1 H, m); 6.86-6.88 (1 H, m); 7.11-7.30 (5 H, m); 3.15 (3 H, s); 2.01-2.03 (2 H, m); 4.52-4.55 (2 H, m); 2.70-2.73 (2 H, m). ${ }^{13}$ C-NMR (500 MHz, CDCl3) $\delta 157.4,137.7,129.8,128.6,128.4,126.3,122.5$, $112.2,109.7,95.4,77.2,76.9,76.7,44.2,33.0,31.9,22.5$

\section{Synthesis of 7-(ethoxycarbonylmethoxylene)- 9-(3-phenylpropyl)-1-methyl- $\beta$-carboline (compound 4)}

Ethyl bromoacetate $(0.594 \mathrm{~g} 3.56 \mathrm{mmol})$ and cesium carbonate $(1.158 \mathrm{~g} 3.56 \mathrm{mmol})$ were added to compound 3 ( $0.749 \mathrm{~g} 2.37 \mathrm{mmol})$ dissolved in anhydrous dimethylformamide (DMF) $(20 \mathrm{~mL})$. Then, the reaction mixture was stirred at room temperature for 15-24 hours. After completion of the reaction as indicated by TLC, the mixture was cooled and diluted with dichloromethane, washed once with water and three times with brine. The organic layer was dried over $\mathrm{Na}_{2} \mathrm{SO}_{4}$ and concentrated. The crude product was purified using column chromatography (dichloromethane/ethanol v/v 30:1).

Yield $=75 \%, \mathrm{R}_{\mathrm{f}}=0.5$ (petroleum ether/acetone $1: 1$ ). ESI-MS m/e $(\mathrm{M}+1)$ 403.4. IR $\left(\mathrm{KBr}, \mathrm{cm}^{-1}\right) 2957,2921$, $1765,1624,1575,1472,1437,1386,1205,1079,815,745$ 1H-NMR (500 MHz, CDCl3) $88.23-8.24$ (1 H, $\mathrm{d}, \mathrm{J}=5.1 \mathrm{~Hz}) ; 7.81-7.82(1 \mathrm{H}, \mathrm{d}, \mathrm{J}=5.13 \mathrm{~Hz}) ; 8.10-8.08$ $(1 \mathrm{H}, \mathrm{d}, \mathrm{J}=8.6 \mathrm{~Hz}) ; 7.11-7.12(1 \mathrm{H}, \mathrm{m}) ; 6.86-6.88(1 \mathrm{H}, \mathrm{m})$; 7.11-7.30 (5 H, m); $3.15(3 \mathrm{H}, \mathrm{s}) ; 2.01-2.03$ (2 H, m); 4.52-4.55 (2 H, m); 2.70-2.73 (2 H, m); $4.71(2 \mathrm{H}, \mathrm{s})$; 4.30-4.34 (2 H, m); 1.32-1.35 (3 H, m) $)^{13}$ C-NMR (500 MHz, CDC13) $\delta 158.6,153.1,149.4,140.1,138.8$, $128.3,128.6,125.8,121.5,120.6,120.2,107.3,96.6,75.6$, $71.0,59.5,58.3,33.5,31.3,16.4,13.6$.

\section{Synthesis of 7-(oxyacetoxy)- 9-(3-phenylpropyl)- 1-methyl- $\beta$-carboline (compound 5)}

A mixture of compound $4(0.716 \mathrm{~g} 1.78 \mathrm{mmol})$, $\mathrm{NaOH}(0.2 \mathrm{~g} 5 \mathrm{mmol})$, ethanol $(10 \mathrm{~mL})$ and $\mathrm{H}_{2} \mathrm{O}(20 \mathrm{~mL})$ was refluxed for $2 \mathrm{~h}$, and the ethanol was removed on the rotary evaporator. The mixture was neutralized $(\mathrm{pH} \mathrm{5)}$ with $5 \mathrm{M} \mathrm{HCl}$ and cooled. The precipitate was collected, washed well with $\mathrm{H}_{2} \mathrm{O}$ and dried in vacuum, then the yellow solid compound 5 was obtained.

Yield $=99 \%$, ESI-MS m/e $(\mathrm{M}+1)$ 375.4. IR $\left(\mathrm{KBr}, \mathrm{cm}^{-1}\right)$ 3445-2851, 1654, 1624, 1576, 1458, 1411, $1312,1231,1139,1055,825,760$

1H-NMR (500 MHz, CDCl3) $\delta 8.23-8.24$ (1 H, d, $\mathrm{J}=5.1 \mathrm{~Hz}) ; 7.81-7.82(1 \mathrm{H}, \mathrm{d}, \mathrm{J}=5.13 \mathrm{~Hz}) ; 8.10-8.08$ $(1 \mathrm{H}, \mathrm{d}, \mathrm{J}=8.6 \mathrm{~Hz}) ; 7.11-7.12(1 \mathrm{H}, \mathrm{m}) ; 6.86-6.88$ (1 H, m); 7.11-7.30 (5 H, m); $3.15(3 \mathrm{H}, \mathrm{s}) ; 2.01-2.03(2 \mathrm{H}$, m); 4.52-4.55 (2 H, m); 2.70-2.73 (2 H, m); $4.71(2 \mathrm{H}, \mathrm{s})$ ${ }^{13} \mathrm{C}-\mathrm{NMR}(500 \mathrm{MHz}, \mathrm{CDCl} 3) \delta 170.1,159.1,142.5,141.0$, $140.4,137.6,134.5,128.2,125.8,122.2,114.4,112.1$, $109.3,94.4,65.5,43.5,40.0,39.6,32.0,31.5,22.7$.

\section{Synthesis of N-(9-phenylpropyl-1-methyl- $\beta$ - carboline 7-oxyacetyl)-(2-amino-2-deoy) - Glucose (2DG-Har-01)}

Compound 5 (0.329 g $0.88 \mathrm{mmol})$ was activated with EDCI (0.253 g $1.32 \mathrm{mmol})$ and N-hydroxysuccinimide $(0.152 \mathrm{~g} 1.32 \mathrm{mmol})$ in DMF $(10 \mathrm{~mL})$. After the mixture was stirred at room temperature overnight, the solution was added with aqueous solution of D-(+)-glucosamine hydrochloride $(0.379 \mathrm{~g} 1.76 \mathrm{mmol})$, and the reaction mixture was stirred at room temperature for another 12 hours. After completion of the reaction as indicated by TLC, the 
DMF was removed on the rotary evaporator. The crude Glucose (2DG-Har-01) was further purified using column chromatography (dichloromethane/ethanol v/v10:1).

Yield $=52 \%, \mathrm{R}_{\mathrm{f}}=0.7$ (dichloromethane/ethanol v/v15:7). ESI-MS m/e $(\mathrm{M}+1)$ 536.5. IR $\left(\mathrm{KBr}, \mathrm{cm}^{-1}\right)$ 3600-3100, 2955, 2923, 2852, 2115, 1777, 1712, 1643, $1555,1464,1377,1263,1082,971,719$

1H-NMR (500MHz, DMSO) $\delta 8.23-8.24(1 \mathrm{H}, \mathrm{d}$, $\mathrm{J}=5.1 \mathrm{~Hz}) ; 7.81-7.82(1 \mathrm{H}, \mathrm{d}, \mathrm{J}=5.13 \mathrm{~Hz}) ; 8.10-8.08(1 \mathrm{H}$, $\mathrm{d}, \mathrm{J}=8.6 \mathrm{~Hz}) ; 7.11-7.12(1 \mathrm{H}, \mathrm{m}) ; 6.86-6.88$ (1 H, m); 7.11-7.30 (5 H, m); 3.15 (3 H, s); 2.01-2.03 (2 H, m); 4.52-4.55 (2 H, m); 2.70-2.73 (2 H, m); 4.71 (2 H, s); 2.50-3.05 (7 H, m, ringGlu-H)

${ }^{13} \mathrm{C}-\mathrm{NMR}(500 \mathrm{MHz}, \mathrm{CDCl} 3) \delta 169.6,161.1,158.3$, $145.4,140.8,137.5,133.5,132.3,129.7,128.2,125.9$, $124.2,114.1,113.5,112.1,94.5,65.0,54.4,41.9,36.2$, $34.1,31.4,28.9,25.2,15.5$.

\section{Synthesis of N-(9-phenylpropyl-1-methyl- $\beta$ - carboline 7-oxyacetyl)- L-Methionine methyl ester (compound 6)}

Compound 5 (0.329 g $0.88 \mathrm{mmol})$ was activated with DCC (0.272 g $1.32 \mathrm{mmol})$ and N-hydroxysuccinimide $(0.152 \mathrm{~g} 1.32 \mathrm{mmol})$ in DMF $(15 \mathrm{~mL})$. After the mixture was stirred at room temperature overnight, the solution was added with L-Methionine methyl ester hydrochloride (0.289 g $1.76 \mathrm{mmol})$, and the reaction mixture was stirred at room temperature for another 10 hours. After completion of the reaction as indicated by TLC, the DMF was removed on the rotary evaporator. The compound 6 was purified using column chromatography (dichloromethane/ethanol v/v 25:1).

Yield $=70 \%, \mathrm{R}_{\mathrm{f}}=0.6$ (dichloromethane $/$ ethanol $\mathrm{v} / \mathrm{v}$ 15:1). ESI-MS m/e $(\mathrm{M}+1)$ 520.2. IR $\left(\mathrm{KBr}, \mathrm{cm}^{-1}\right) 3313$, 2957, 2922, 2851, 1743, 1624, 1533, 1455, 1261, 1027, 804,752

1H-NMR (500 MHz, CDCl3) $88.36-8.37(1 \mathrm{H}, \mathrm{d}$, $\mathrm{J}=5.0 \mathrm{~Hz}) ; 8.09-8.11(1 \mathrm{H}, \mathrm{d}, \mathrm{J}=10 \mathrm{~Hz}) ; 7.90-7.91(1 \mathrm{H}$, $\mathrm{d}, \mathrm{J}=5.0 \mathrm{~Hz}) ; 7.40-7.43(2 \mathrm{H}, \mathrm{m}) ; 7.35-7.37$ (1 H, m); 7.27-7.29 (2 H, d, J = $10 \mathrm{~Hz}) ; 7.04-7.06(1 \mathrm{H}, \mathrm{m})$; 6.80-6.81 (1 H, d, J = 5.0 Hz); 3.05 (3 H, s); 2.25-2.28 (2 H, m); 4.89-4.93 (2 H, m); 2.84-2.86 (2 H, m); 3.82 (2 H, s); 2.12 (3 H, s); 2.56-2.59 (2 H, m); 4.62-4.69 $(2 \mathrm{H}, \mathrm{m}) ; 4.52-4.55(1 \mathrm{H}, \mathrm{m}) ; 2.75(3 \mathrm{H}, \mathrm{s})^{13} \mathrm{C}-\mathrm{NMR}$ (500 MHz, CDCl3) $\delta 172.7,171.9,159.1,143.8,140.1$, $139.2,135.2,135.0,130.8,128.8,128.3,126.7,123.3$, $115.6,112.9,110.3,94.5,76.9,67.7,52.7,51.2,32.8$, $31.4,30.9,29.3,20.5,14.0$

\section{Synthesis of N-(9-phenylpropyl-1-methyl- $\beta$ - carboline 7-oxyacetyl)- L-Methionine bromate (MET-Har-02)}

A mixture of $6(0.322 \mathrm{~g} 0.62 \mathrm{mmol})$ and benzyl bromide $(0.632 \mathrm{~g} 6 \mathrm{mmol})$ in ethyl acetate $(4 \mathrm{~mL})$ was refluxed for $12 \mathrm{~h}$. The reaction mixture was monitored by TLC and then cooled at $0^{\circ} \mathrm{C}$. The yellow solid METHar-02 was filtered under reduced pressure and washed well with ethyl acetate, and then recrystallized from ethanol, dried in vacuum to give yellow crystals.

Yield $=28 \%$, ESI-MS m/e (M+) 596.2. IR (KBr, $\mathrm{cm}^{-1}$ ) 3405-3028, 2951, 2924, 2855, 2793, 1744, 1622, $1537,1454,1343,1209,1068,816,733,701 .{ }^{1} \mathrm{H}-\mathrm{NMR}$ (500 MHz, DMSO) $\delta 6.02-8.80$ (15 H, m); 2.99 (3 H, s); 2.10-2.11 (2 H, m); 4.88-4.52 (2 H, m); 2.67-2.68 (2 H, m); 3.78 (2 H, s); 2.59 (3 H, s); 2.73-2.76 (2 H, m); 4.64-4.67 (2 H, m); 5.00-5.03 (1 H, m) ${ }^{13}$ C-NMR (500 MHz, DMSO) $\delta 172.6,171.8,134.1,129.3,128.9$, $128.7,128.3,128.2,126.7,126.7,77.7,40.0,39.8,39.6$, $39.4,39.3,39.1,38.9,35.1,34.8,31.1,28.9,28.5,25.3$, $25.1,21.9$

\section{Characterization of 2DG-Har-01 and MET-Har-02}

Q-TOF Micro Mass Spectrometer (Waters), Nuclear Magnetic Resonance Spectrometer (BRUKER) and Fourier Transform Infrared spectroscopy (Waters) were used to validate the successful synthesis of 2DG-Har-01 and MET-Har-02.

\section{Proliferation inhibition assays}

The effect of products 2DG-Har-01 and METHar-02 on human cancer cell growth were carried out on HepG2, SMMC-7721, HuH7, LOVO, MCF-7 and L02 using MTT assay according to the following procedures. Cells were plated at a density of $5 \times 10^{3}$ cells/well in 96-well plates and incubated overnight. Cells were then incubated with indicated concentration of 2DG-Har-01 MET-Har-02, or controls (harmine or 5-FU) for $48 \mathrm{~h}$. Five replicates were performed for each concentration. MTT solution $(5 \mathrm{mg} / \mathrm{mL})$ was add each well. After incubation for $4 \mathrm{~h}$, the medium was discarded and the formazan crystals was dissolved in $100 \mu \mathrm{L}$ DMSO. The plates were shaken for $15 \mathrm{~min}$. The optical density (OD) value was measured at $490 \mathrm{~nm}$ with a microplate reader. The proliferation rate was calculated by the following equation: proliferation rate $(\%)=\left(\mathrm{OD}_{\text {treated }} / \mathrm{OD}_{\text {control }}\right) \times 100 \%$.

\section{Colony formation assay}

HepG-2 cells were trypsinized and seeded in 6-well microplates (500 cells/well) in $2 \mathrm{~mL}$ of complete RPMI1640 and were examined microscopically to confirm that only single cell without clumps had been plated. Then thecellswere treated with theindicated concentrations METHar-02 and harmine for 7 days. During colony growth, the culture medium was replaced every 3 days. Finally, the cells were fixed with methanol and stained with crystal violet. Imagesof thecolonies were captured by a digital camera. Colonies were visualized by microscopy with an 
Olympus microscope (Olympus, BX51, Tokyo, Japan). The colonies with more than 50 cells were counted under light microscope. Colony formation rate was calculated with the equation: colony formation rate $=$ (number of colonies/ number of seeded cells). Each test was repeated in triplicate.

\section{Apoptosis analysis}

HepG-2 cells growing on 6-well dishes were treated with chemicals in the presence or absence of harmine and MET-Har-02 for $24 \mathrm{~h}$ and total cells were collected. The percentage of apoptotic cells was evaluated by staining $1 \times$ $10^{6}$ cells with annexin V-FITC (Beyotime) and propidium iodide (Beyotime) in binding buffer for $10 \mathrm{~min}$ at room temperature in the dark. The samples were analyzed by flow cytometry (FACScalibur, Becton-Dickinson) within $1 \mathrm{~h}$ to determine the percentage of cells displaying annexin $\mathrm{V}+$ /propidium iodide-(early apoptosis) or annexin $\mathrm{V}$-/propidium iodide + staining(late apoptosis). Three independent experiments were performed for each assay condition.

\section{Morphological assay}

About $3 \times 10^{5}$ HepG-2 tumor cells were seeded at the confocal petri dish and incubated at $37^{\circ} \mathrm{C}$ for $24 \mathrm{~h}$ and treated with MET-Har-02 for 24 h. Hoechst 33342 (Beyotime) were added in 30 mins advance before laser confocal microscopy observation (LCFM, FluoView ${ }^{\mathrm{TM}}$ FV1000, Olympus, Japan)

\section{In vivo antitumor activity analysis by tumor xenograft model}

S180 cells $\left(5 \times 10^{6}\right)$ were subcutaneously injected into the Kunming mice ( $n=10$ per group). As the tumors grew up to a diameter of $0.2-0.5 \mathrm{~cm}$, the mice were used for treatment. The active compound 2DG-Har-01 and MET-Har-02 were tested for in vivo antitumor activity in the Ehrlich solid carcinoma (S180) assay model, while harmine and normal saline (NS) were used as the positive and negative controls respectively. The effect of 2DG-Har-01 and MET-Har-02 treatments on S180 tumor growth were assessed by measuring tumor volume with a sliding caliper and body weight. We measured tumor volume after $96 \mathrm{~h}$ post inoculation. The mice were randomly assigned into four groups, and each group was treated once every other day by injection of $0.2 \mathrm{~mL}$ of the solution of $20 \mathrm{mg} / \mathrm{kg}$ of 2DG-Har-01, MET-Har-02 and harmine in NS for six times. After treatment, tumor sizes were measured every other day until average tumor volume of control group reached approximate $3000 \mathrm{~mm}^{3}$. At this time, all mice were killed and the tumors were weighed. Body weight changes were also monitored every other day. The inhibition ratio (IR) was defined as follows: Inhibition ratio $(\%)=((\mathrm{Wc}-\mathrm{Wt}) / \mathrm{Wc}) \times 100 \%$. Wc and
Wt stand for the average tumor weight for control group and treatment group, respectively.

After the antitumor activity assay performed on the Kunming mice, we also conducted the experiment on the nude mice which were injected with human breast tumor cells MCF-7. Similarly, the tumor bearing nude mice were also divided into 3 groups $(n=10)$ and treated on days 7 , 11,15 and 19 post -inoculation by the same procedures as Kunming mice group, with the dose of $20 \mathrm{mg} / \mathrm{kg}$ harmine and MET-Har-02. The therapeutic efficacies were assessed by measuring tumor volume and body weight every other day till the 21 th day and the survival rate were recorded.

\section{Histology examination}

To further investigate the side effects of harmine and MET-Har-02 on various organs of the treated mice, histological analysis of different organs was conducted by the established technique.

\section{Acute toxicities assay}

The acute toxicity of 2DG-Har-01, MET-Har-02 and harmine (as control) to animal subjects were investigated on the normal mice. Briefly, 30 Kunming mice (aged 3-4 weeks, weighed 18-22 g, equal number of male and female subjects) were divided randomly into 4 groups including the control group. Mice in the control group were injected with PBS buffer $(0.2 \mathrm{~mL})$. The mice were given an ip injection of $10,50,100$, 200 and $500 \mathrm{mg} / \mathrm{kg}$ of 2DG-Har-01, MET-Har-02 and harmine in $0.2 \mathrm{~mL}$ of $0.9 \%$ saline. After administration, the mice were observed thoroughly for the onset of any immediate neural toxicities and delayed effects. The mice were monitored continuously for 10 days to observe any abnormal behaviors or death. All animals were sacrificed on the $10^{\text {th }}$ day and checked macroscopically for possible damage to the heart, liver, spleen, lung and kidneys. The weight changes of the tissues and bodies were assessed and compared. Blood was drawn from the eye socket. The serum biochemical parameters including aspartate aminotransferase (AST), alanine aminotransferase (ALT), blood urea nitrogen (BUN) and creatinekinase (CK) indexes of the blood samples were examined.

\section{Statistical analysis}

All data were reported as the mean SD of $n$ independent measurements. Statistical analysis was performed by using Student's $t$-test with statistical significance assigned for $P$ value of $<0.05$.

\section{CONCLUSION}

Harmine and its reported derivatives present several drawbacks arising from the relative weak antitumor 
activities and the serious neurotoxicity. To overcome the limitation, we successfully conjugated two novel harmine derivatives with different tumor metabolic specific lignads. The two novel harmine derivatives i.e. 2DG-Har-01 and MET-Har-02 showed higher antitumor efficiency and lower systemic and neural toxicity than un-modified harmine in a broad spectrum of tumor lines. In particular, MET-Har-02 displayed better antitumor activity than that of 2DGHar-01. Our results demonstrated that MET-Har-02 is a promising candidate for targeted cancer therapy.

\section{ACKNOWLEDGMENTS}

The authors are grateful to Natural Science Foundation Committee of China (NSFC 81220108012, 61335007, 81371684, 81000666, 81171395 and 81328012 ) for their financial support.

\section{FINANCIAL INFORMATION}

This work was financially supported by the National Natural Science Foundation of China (NSFC 81220108012, 61335007, 81371684, 81000666, 81171395 and 81328012 )

\section{DISCLOSURE OF POTENTIAL CONFLICTS OF INTEREST}

The authors declare that no conflict of interest exists in the present study.

\section{REFERENCES}

1. Cao RH, Peng WL, Wang ZH, Xu A. $\beta$-Carboline Alkaloids: Biochemical and Pharmacological Functions. Curr Med Chem. 2007; 14:479-500.

2. Patel K, Gadewar M, Tripathi R, Prasad SK, Patel DK. A review on medicinal importance pharmacological activity and bioanalytical aspects of beta-carboline alkaloid “'Harmine', Asian Pac J Trop Biomed. 2012; 2:660-4.

3. Liu JW, Zhao M, Qian KD, Zhang X, Lee KH, Wu J, Liu YN, Peng S. Benzyl 1, 2, 3, 5, 11, 11a-hexahydro-3, 3-dimethyl-1-oxo-6H-Imidazo [3', 4': 1, 2] pyridine [3, 4-b] indole-2-substituted acetates: One-pot-preparation, anti-tumoractivity, docking toward DNA and 3D QSAR analysis. Bioorg Med Chem. 2010; 18:1910-7.

4. Chen Q, Chao RH, Chen HS, Hou X, Yan H, Zhou S, Peng W, Xu A. Antitumor and neurotoxic effects of novel harmine derivatives and structure-activity relationship analysis. Int. J. Cancer. 114:675-82.

5. Aquilino Barbosa V, NazariFormagio A.S, Cristina Savariz F, Foglio MA, Spindola HM, de Carvalho JE, Meyer E, Sarragiotto MH. Synthesis and antitumor activity of $\beta$-carboline 3-substituted-carbohydrazide) derivatives. Bioorg Med Chem. 2011; 19:6400-8.
6. Nussbaumer S, Bonnabry P, Veuthey JL, Fleury-Souverain S. Analysis of anticancer drugs: a review. Talanta. 2011; 85:2265-89.

7. Raschi E, Vasina V, Ursino MG, Boriani G, Martoni A. De Ponti F. Anticancer drugs and cardiotoxicity: insights and perspectives in theera of targeted therapy. PharmacolTher. 2010; 125:196-218.

8. Ma CM, Cao RH, Shi BX, Zhou X, Ma Q, Sun J, Guo L, Yi W, Chen Z, Song H. Synthesis and cytotoxic evaluation of 1-carboxamide and 1-amino side chain substituted $\beta$-carbolines. Eur J Med Chem. 2010; 45:5513-19.

9. Cao RH, Yi W, Wu QF, Guan X, Feng M, Ma C, Chen Z, Song H, Peng W. Synthesis and cytotoxic activities of 1-benzylidine substituted $\beta$-carboline derivatives. Bioorg Med ChemLett. 2008; 18:6558-61.

10. Cao RH, Guan XD, Shi BX, Chen Z, Ren Z, Peng W, Song H. Design synthesis and 3D-QSAR of $\beta$-carboline derivatives as potent antitumor agents. Eur J Med Chem. 2010; 45:2503-15.

11. Formagio AS1, Tonin LT, Foglio MA, Madjarof C, de Carvalho JE, da Costa WF, Cardoso FP, Sarragiotto MH. Synthesis and antitumoral activity of novel 3-(2-substituted-1, 3, 4-oxadiazol-5-yl) and 3-(5-substituted-1, 2, 4-triazol-3-yl) $\beta$-carboline derivatives. Bioorg Med Chem. 2008; 16:9660-67.

12. Ma CM, Cao RH, Shi BX, Li S, Chen Z, et al. Synthesis and cytotoxic evaluation of N2-benzylated quaternary $\beta$-carboline amino acid ester conjugates. Eur J Med Chem. 2010; 45:1515-23.

13. Chen ZY, Cao RH, Yu L, Shi B, Sun J, Guo L, Peng W, Ren Z, Song H. Synthesis, cytotoxic activities and DNA binding properties of $\beta$-carbolin Derivatives. Eur J Med Chem. 2010; 45:4740-45.

14. Chen ZY, Cao RH, Shi BX, Yi W, Yu L, Song H, Ren Z, Peng W. Synthesis of novel $\beta$-carbolines with efficient DNA-binding capacity and potent cytotoxicity. Bioorg Med Chem Lett. 2010; 20:3876-79.

15. Chen ZY, Cao RH, Shi BX, Yi W, Yu L, Song H, Ren Z. Synthesis and Biological Evaluation of Novel $\beta$-Carbolines as Potent Cytotoxic and DNA Intercalating Agents. Chem Pharm Bull (Tokyo). 2010; 58:901-7.

16. Chen ZY, Cao RH, Shi BX, Guo L, Sun J, Ma Q, Fan W, Song H. Synthesis and biological evaluation of 1,9-disubstituted $\beta$-carbolines as potent DNA intercalating and cytotoxic agents. Eur J Med Chem. 2011; 46:5127-37.

17. Ikeda $R$, Iwaki $T$, Iida $T$, Okabayashi $T$, Nishi $E$, Kurosawa M, Sakai N, Konakahara T. 3-Benzylamino$\beta$-carboline derivatives induce apoptosis through $\mathrm{G} 2 / \mathrm{M}$ arrest in human carcinoma cells HeLa S-3. Eur J Med Chem. 2011; 46:636-6.

18. Qiu X, Du YH, Lou B, Zuo Y, Shao W, Huo Y, Huang J, Yu Y, Zhou B, Du J, Fu H, Bu X. Synthesis and Identification of New 4-Arylidene Curcumin Analogues as 
Potential Anticancer Agents Targeting Nuclear Factor-KB Signaling Pathway. J Med Chem. 2010; 53:8260-73.

19. Endo S, Matsunaga T, Kanamori A, Otsuji Y, Nagai H, Sundaram K, El-Kabbani O, Toyooka N, Ohta S, Hara A. Selective Inhibition of Human Type-5 17ß-Hydroxy-steroid Dehydrogenase (AKR1C3) by Baccharin, a Component of Brazilian Propolis. J Nat Prod. 2012; 75:716-21.

20. Liu J, Zheng CH, Ren XH, Zhou F, Li W, Zhu J, Lv JG, Zhou YJ. Synthesis and Biological Evaluation of 1-Benzylidene-3, 4-Dihydronaphthalen-2-one as a New Class of Microtubule-Targeting Agents. J Med Chem. 2012; 55:5720-33.

21. Nam S, Xie Jun, Perkins A, Ma Y, Yang F, Wu J, Wang Y, $\mathrm{Xu}$ RZ, Huang W, Horne DA, Jove R. Novel synthetic derivatives of the natural product berbamine inhibit Jak2/ Stat 3 signaling and induce apoptosis of human melanoma cells. Mol Oncol. 2012; 6:484-93.

22. Yao NH, Chen CY, Wu CY, Motonishi K, Kung HJ, Lam KS. Novel Flavonoids with Antiproliferative Activities against Breast Cancer Cells. J Med Chem. 2011; 54:4339-49.

23. Guo J, Du C, Shan L, Zhu H, Xue B, Qian Z, Achilefu S, $\mathrm{Gu}$ Y. Comparison of near-infrared fluorescent deoxyglucose probes with different dyes for tumor diagnosis in vivo. Contrast Media Mol Imaging. 2012; 7:289-301.

24. Mahounga DM, Shan L, Jie C, Du C, Wan S, Gu Y. Synthesis of a novel L-methyl-methionine-ICG-Der-02 fluorescent probe for in vivo near infrared imaging of tumors. Mol Imaging Biol. 2012; 14:699-707.

25. Ganapathy V, Thangaraju M, Prasad PD. Nutrient transporters in cancer: relevance to Warburg hypothesis and beyond. PharmacolTher. 2009; 121:29-40.

26. Mohanti BK, Rath GK, Anantha N, Kannan V, Das BS, Chandramouli BA, Banerjee AK, Das S, Jena A, Ravichandran R, Sahi UP, Kumar R, Kapoor N, et al. Improving cancer radiotherapy with 2-deoxy-Dglucose:phase I/II clinical trials on human cerebral gliomas. Int J RadiatOncolBiolPhys. 1996; 35:103-11.

27. Miot-Noirault E, Reux B, Debiton E, Madelmont JC, Chezal JM, Coudert P, Weber V. Preclinical investigation of tolerance and antitumour activity of new fluorodeoxyglucose-coupled chlorambucil alkylating agents. Invest New Drugs. 2011; 29:424-33.

28. Simons AL, Ahmad IM, Mattson DM, Dornfeld KJ, Spitz DR. 2-Deoxy-D-glucose combinedwithcisplatin enhances cytotoxicity viametabolic oxidative stress in human head and neck cancer cells. Cancer Res. 2007; 67:3364-70.

29. Cao J, Cui SS, Li SW, Du C, Tian J, Wan S, Qian Z, Gu Y, Chen WR, Wang G. Targeted Cancer Therapy with a 2-Deoxyglucose-Base Adriamycin Complex. Cancer Res. 2013; 73:1362-73.

30. Hediger MA, Rhoads DB. Molecular physiology of sodiumglucose cotransporters. Physiol Rev. 1994; 74:993-1026.

31. Hazari PP, Shukla G, Goel V, Chuttani K, Kumar N, Sharma R, Mishra AK. Synthesis of specific SPECTradiopharmaceutical for tumor imaging based on methionine: 99mTc-DTPA-Bis(methIo-nine). BioconjugChem. 2010; 21:229-39.

32. Lin J, Raoof DA, Thomas DG, Greenson JK, Giordano TJ, Robinson GS, Bourner MJ, Bauer CT, Orringer MB, Beer DG. L-type amino acid transporter-1 overexpression and melphalan sensitivity in Barrett's adenocarcinoma. Neoplasia. 2004; 6:74-84.

33. Frederick R, Bruyere C, Vancraeynest C, Reniers J, Meinguet C, Pochet L, Backlund A, Masereel B, Kiss R, Wouters J. Novel TrisubstitutedHarmine Derivatives with Original in Vitro Anticancer Activity. J Med Chem. 2012; 55:6489-6501.

34. Reniers J, Robert S, Frederick R, Masereel B, Vincent S, Wouters J. Synthesis and evaluation of b-carboline derivatives as potential monoamine oxidase inhibitors.Bioorg Med Chem. 2011; 19:134-144.

35. Park SE, Shin WT, Park C, Hong SH, Kim GY, Kim SO, Ryu $\mathrm{CH}$, Hong $\mathrm{SH}$, Choi YH. Induction of apoptosis in MDA-MB-231 human breast carcinoma cells with an ethanol extract of Cyperusrotundus L. by activating caspases. Oncol Rep. 2014; 22.

36. Fan L, Ma Y, Liu Y, Zheng D, Huang G. Silymarin induces cell cycle arrest and apoptosis in ovarian cancer cells. Eur J Pharmacol. 2014; 18. 